Judicial policy-making and Europeanization

the proportionality of national control and administrative discretion

Martinsen, Dorte Sindbjerg

Published in:

Journal of European Public Policy

DOI:

10.1080/13501763.2011.599962

Publication date:

2011

Document version

Early version, also known as pre-print

Citation for published version (APA):

Martinsen, D. S. (2011). Judicial policy-making and Europeanization: the proportionality of national control and administrative discretion. Journal of European Public Policy, 18(7), 944-961.

https://doi.org/10.1080/13501763.2011.599962 


\title{
Judicial policy-making and Europeanization: the proportionality of national control and administrative discretion
}

\author{
Dorte Sindbjerg Martinsen \\ Journal of European Public Policy (2011), Vol. 18 (7): 944-961. \\ http://www.tandfonline.com/doi/abs/10.1080/13501763.2011.599962\#.VCVewLccS70
}

\begin{abstract}
Judicial policy-making is having an increasing impact on political domains traditionally guarded by national sovereignty. This paper examines how the European judiciary has expanded Community competences into the policy domains of welfare and immigration, followed by subsequent Europeanization, against the preferences of the member governments. It finds that the principle of proportionality constitutes a most powerful means for the European Court to strike the balance between supranational principles and national policy conditions and administrative discretion. While the Court has previously been cautious to apply the principle beyond economic law, it no longer treads as reluctantly, instead generally limiting the inner core of national policy control, i.e. the capacity of the national executive to detail, condition and administer national policies in almost all domains.
\end{abstract}


Key words: Judicial policy-making and Europeanization; principle of proportionality; national control; administrative discretion; welfare and immigration policies

\section{Introduction}

Judicial policy making is having an increasing impact on political domains traditionally severely guarded by national sovereignty such as immigration policy, healthcare, the labour market and minimum welfare benefits. The European Court of Justice (ECJ) has a long and well-known history as an integrative motor of the European Community, hereby conditioning and limiting national competences. It has long been a key institution for drawing and redefining the boundaries of the supranational and national communities. In this respect, the recent expansion of Community scope by means of judicial interpretation is not a new phenomenon. Rather, it merely confirms a Court which is neither politically restrained nor displaying signs of self-restraint, continuing instead to bring supranational competences into what national politicians and bureaucracies thought their exclusive domain. However, the puzzle still remains how the ECJ manages to intervene in policy areas where political control and administrative discretion at first sight remain strictly national, and political preferences to keep it that way are indeed explicit and relatively fixed - and even often literally substantiated by Community secondary law. This paper thus examines how the ECJ has expanded Community competences into policy domains of constituted national boundaries and tight national control.

The how question may be especially relevant to scholars of political science and public administration interested in judicial policy-making and its effects beyond the courtroom. Many such scholars will question the de facto effects of judicial policy-making, pointing out the arsenal of conditional and restrictive means that national executives have at their disposal to hinder unwanted 
Europeanization. It is first when such restrictive means set out in national laws and administrative practices can be overcome that we can speak of 'judicial Europeanization', defined as a de facto national effect caused by the ECJ judicial policy-making. The argument of this article is that also in the policy fields of welfare and immigration, the interpretations of the ECJ cause judicial policymaking, or policy creation, which reaches beyond the Court room and therefore even in these areas of high political salience we find judicial Europeanization. The analysis below demonstrates that the principle of proportionality as a general principle of Community law is a powerful instrument applied by the Court when extending Community competences, among other aspects because it quite effectively targets the conditional and restrictive means in national rules and practices often set to hinder the impact of EU regulation.

By applying the principle of proportionality, the judiciary possesses a powerful means through which to de facto enhance the scope of Community competences (De Búrca, 1993). By ruling national policies and administrative practices 'disproportionate', the ECJ has a strong principle through which supranational powers can be enhanced. It has an instrument that it can apply in a rather ad hoc manner should it find national measures unjustifiable, even though they are literally inserted as legitimate means in the secondary legislation of the Community. A proportionality assessment of the personal situation of the claimant may overrule what national executives thought were national conditions compatible with Community law (Spaventa 2008, p. 40). Although the principle of proportionality is designed to find the optimal balance between justified national conditions and EU principles, that balance is often struck in favour of the latter. Proportionality thus constitutes a doctrinal means to expand judicial power with direct implications for policy-making and its administration (Stone Sweet and Mathews 2008). 
On a more general level, the compliance with ECJ rulings has been said to be 'contained' (Conant 2002). Member states are not automatically giving in to EU imperatives where they want to guard their sovereignty. Furthermore, Court decisions clearly provide more room for interpretation when national executives are to implement the supranational case law than when implementing secondary legislation (Wasserfallen 2010). Welfare and immigration policies are indeed policy areas where member states have jealously guarded their autonomy to define who are to be members of the national communities. In practice, this is done by the executive inserting various conditions in national rules which must be fulfilled to enter the national community and allowing a high level of discretion when exercising these rules. Thresholds which have to be overcome to realize European rights and their discretionary exertion are likely to hinder the effective reach of Europe. By means of the expansive interpretation of European citizenship and the principle of proportionality, however, the ECJ evaluates the justifiability of these conditions. It thus evaluates what may be regarded as the inner core of national control; the power to detail, condition and administer national policies.

The paper analyses two domains in which national control has remained strong but faces severe challenges. The first analysis concerns the area of welfare and examines how the ECJ increasingly questions the justifiability of national conditions in order to earn the right to minimum social benefits and how the national level has responded by filtering the eligibility for social provisions through national residence clauses, as exemplified by the case of the United Kingdom. The second analysis examines national immigration policies and family unification rights and analyses the Court's review of discriminatory national policies and administrative discretion. In addition, the impact of judicial policy-making beyond the courtroom is examined with Denmark as illustrative case. The two policy areas share the same point of reference against which rights are generated and 
boundaries redrawn, namely European citizenship and a person's right to reside freely within the EU.

\subsection{Enhancing Competences, Redrawing Boundaries}

The ECJ's judicial policy-making has become known in almost all policy areas. The term may be defined in the same way as 'judicial activism', understood as the process whereby juridification expands and differentiates into new regulatory domains (Blichner and Molander, 2008, p. 42). This understanding implies a subsequent consequential process whereby the boundaries of national competences and autonomy are redrawn - and eventually pushed back. It is also a process in which the domain of 'political' policy-making is pushed back and/or conditioned by 'non-political' forces (Scharpf, 2001; 2009). It thus affects the scope condition of making policy and its administration.

Questioning the effects of judicial policy-making therefore cannot be assessed as a power shift at the supranational level alone; between the forces of 'law' and 'politics' in the EU. It also implies a consequential logic. Both political and administrative responses at the national levels must be taken into account in order to assess the true impact of judicial integration. Implementation and Europeanization research would hypothesize that it may well be that subsequent national responses to judicial interpretations compensate, differentiate or neutralize unwanted extensions of supranational competences (Radaelli, 2003). The likelihood of such resistance is expected to be greater when it comes to ECJ case law compared to EU secondary law (Wasserfallen 2010), as the general implication of individual cases is often unclear and the discretionary span for how to implement them is wider. The need - and guidelines how - to comply thus become vaguer or more diffuse. 
The inherent tensions between the regulatory competence of the EU and the administrative powers of the Member States may initially amputate the effective reach of judicial integration. In the daily practices of executing EU norms and rules, national sovereignty may be guarded by an intact inner core of national control through which member states maintain the power to condition and administer access to their communities. However, the analysis below points out how judicial interpretations increasingly address this inner core, confronting the various thresholds that member states establish to hinder unwanted Europeanization.

European citizenship is a powerful demonstration of the creative abilities of the European Court, but also how it is met at the national level. The European Court has been the primary institution to add meaning to the rather empty concept of Union citizenship. Through expansive interpretations on the free movement rights of the citizenry, the Court has elevated supranational citizenship from its embryonic stage (Jacobs 2007; Olsen 2008) to one of the Community's most important principles (Wind, 2009). Granting the free movement principles and the principle of nondiscrimination fundamental or constitutive status in the Community order has developed and extended the rights enjoyed by Community nationals when moving from one Member State to another.

However, Member States are not simply accepting such intervention out of their respect for the rule of law; while supranational rights are enhanced in the courtroom, national control is intensified through alternative - often more discrete - means (Conant, 2002). People might formally be treated equally, but the adoption and administration of various conditions for eligibility create de facto 
discriminatory effects. The thresholds to enter the national community of a host member state are many and high.

The European Court's use of the principle of proportionality and assessments of administrative practices become central in this respect, as they directly challenge such thresholds and confront powerful remains of national control.

\subsection{The Principle of Proportionality: Setting Limits on Policy Execution}

The principle of proportionality is known as a principle of judicial assessment in both national and transnational law, here for Community law (Stone Sweet and Mathews 2008). The ECJ can review both Community actions and national measures in the light of the principle. When assessing proportionality, the Court carries out a form of balancing inquiry. In this balancing act, the Court examines the weight and justifiability of policy means and ends, often in the light of fundamental Community aims such as the internal market and the constitutive free movement principles. A proportionality test carried out by the ECJ will normally contain three steps, evaluating; 1) the suitability of the measure to achieve its stated aim; 2) whether the measure was necessary to achieve this aim; and 3) whether the measure imposes an excessive burden on the individual in the light of the desired aim, i.e. criteria of reasonableness and an act of balancing benefits and costs of the measure (Craig and De Búrca 2008, p. 545; Stone Sweet and Mathews 2008, pp. 75-76).

However, the principle has developed into one of the general principles in Community law, which is traditionally particularly important in the field of economic law (Tridimas, 2006, p. 137). According to Tridimas, the test of proportionality has traditionally been applied to agricultural law, external trade, charge-imposing measures, penalties and sanctions (Tridimas, 2006, p. 138). 
Moreover, earlier Court assessments suggested a more restrained judiciary, less willing to apply the principle against national measures if the national policy reviewed was of a sensitive nature or for example considered national interests and competence such as social policy objectives (De Búrca, 1993, p. 114). The Court no longer seems to step that reluctantly. As legal scholars have pointed out (Tridimas, 2006, p. 138; Hailbronner 2005; Spaventa 2008) and as will be demonstrated below, the principle has recently been applied to new areas of Community regulation, including healthcare, labour market regulation, welfare and immigration policy, in a rather creative manner. Proportionality assessments have become more pervasive and its 'personalized' and/or ad hoc application "brings about a qualitative change in the expansion of judicial review of national rules" (Spaventa 2008, p. 40). The principle therefore constitutes a contemporary elastic and powerful means for the judiciary to expand EU competences and review national measures, since it can be added to new situations and new regulatory domains without further justification. It constitutes a flexible tool of judicial review.

The principle requires that action must be proportionate to its objective and is founded on the idea that the individual must be protected from the state. The principle addresses both the supranational and national levels of policy execution. It may be used to challenge Community action, but can also be invoked to challenge national measures in the light of Community law. The principle provides a general point of reference against which to evaluate national measures and provides extended opportunity for the European judiciary to intervene in the domain of the national legislatures and administrations. Obviously, it cannot be disaggregated from the other interpretative issues that the Court considers in the case at hand, and we will see it tightly coupled to Union citizenship and the free movement of European citizens in the following. A national measure which contradicts the fundamental provisions of the Treaty is incompatible with Community law unless it is necessary to 
achieve a legitimate aim. Such legitimate purpose could include the need to protect the national budget balance, the social security system, public health or public security. By reviewing national measures against the principle of proportionality, the Court has a position from which to assess the justifiability and reasonableness of national policies and administration in the light of the supreme Community legal order. This means that the principle may work in two ways; the Court may find that national measures are necessary, are proportionate in the light of what it tries to protect or achieve, but it may also review national means and ends as disproportionate. However, the Court's interpretation seems to result mainly in the latter, challenging national measures and its review becoming more intensive over time (Spaventa 2008; Stone Sweet and Mathews 2008; Craig and De Búrca 2008, p. 550).

In the light of the principle, national authorities are obliged to prove that policies are 'suitable' and 'necessary' if they constitute obstacles to the greater aim of the Community polity. The principle places limitations on both the substance of national policies and on the procedures for how such policies are executed. It evaluates social, economic and political choices as well as the attached administrative procedures. The reviewable power of the Court generates its own asymmetry. While the tests of suitability and necessity likely give full value to the European freedoms, countervailing national arguments have greater difficulties proving that contradictory measures are necessary and acceptable (Scharpf, 2009, p. 195).

Due both to its substantive and procedural content, the Court's use of the principle addresses the core dimensions of national control. It constitutes a strong supranational prism through which legislative and administrative actions are reviewed (de Búrca, 1993, p. 108) and often perceived by legal scholars to be 'the most far-reaching ground for review, the most potent weapon in the arsenal 
of a public law judge' (Tridimas, 2006, p. 140) and the 'magic key', the 'most important yardstick for determining the manner and extent of restrictions of rights granted by law' (Hailbronner, 2005, pp. 1253-1254).

The principle accentuates central dilemmas in the interplay between law and politics as seen in more recent judicial interventions in national policy-making. In the field of healthcare, national means of control have been put to test by the ECJ. In a line of case-law, the Court has found that national measures fail the test of proportionality when the national executive is unable to justify and prove that the condition of prior authorization in order to be treated at a hospital in another Member State is a suitable and necessary instrument of control (Martinsen 2009). The principle has also been invoked in the line of case law considering minimum wages, collective actions and bargaining, where the Court found that the national actions taken were not sufficiently evidenced, not proved necessary, and were therefore disproportionate in the light of Community law. ${ }^{\mathrm{i}}$

In the below, the Court's scrutiny of the proportionality of national conditions and restrictions will be examined in terms of welfare minimum benefits and immigration policy; two policy areas traditionally guarded by strong means of national control.

\subsection{EU citizenship rights vs. national residence clauses}

The development of Union citizenship is an important Community steppingstone from which traditional means of national control are increasingly challenged. Such challenge is clear in relation to the national competence to reserve social benefits to the national Community. Minimum social benefits and student benefits have traditionally been reserved for national citizens or granted 
through a filter of considerable national conditions but are increasingly interpreted in the light of Union citizenship - and of proportionality (Spaventa 2008).

When coupled with proportionality, the power of European citizenship rights becomes apparent in the cases concerning students as well as those concerning the rights of jobseekers. The Court's conclusions in Grzelczyk, which addressed the Belgian minimex, extended access to social assistance on the basis of European citizenship with reference to the fundamental status of Union citizenship (Jacobs 2007; Wasserfallen 2010). ${ }^{\text {ii }}$

The case of Trojani ${ }^{\text {iii }}$ followed suit. Here, the Court considered the proportionate exertion of the conditions inserted in the relevant residence directive ${ }^{\text {iv }}$. Although the residence directive conditioned residence rights on the person having sufficient resources as well as being covered by a sickness insurance, the Court stated that the national authorities must consider the individual situation in the light of what is proportionate (paras. 34 and 46 of C-456/02, Trojani). The national exercise of limits and conditions to Community rights must comply with 'personalized' assessment of the principle of proportionality (Spaventa 2008; para. 46 of C-456/02 Trojani). In this way, the autonomy to exert conditions, although stated as a legitimate national means in secondary Community legislation, becomes subjugate to an ECJ measure of what is justifiable in the personalized situation. The same was emphasized in Baumbast ${ }^{\nu}$, where the Court found it disproportionate to refuse a residence permit to $\mathrm{Mr}$ Baumbast on the grounds that he was not covered by sufficient sickness insurance in the UK (paras. 91-94 of C-413/99, Baumbast; Jacobs 2007). ${ }^{\text {vi }}$ Although the national rules evaluated had correctly implemented the conditions set out in Community secondary law, i.e. Directive 90/364, the exercise of the condition in the personal situation of Mr Baumbast was found disproportionate (Spaventa 2008, p. 40). 
The Court's cluster of case-law cannot, however, be interpreted as a linear expansion of free movement rights. Collins ${ }^{\text {vii }}$ could be regarded as a setback in this regard (Wind, 2009, p. 261). However, the case leaves room for a more ambiguous interpretation of the question of the scope and limits of the welfare rights of those moving within the Community. Collins concerned the UK income-based jobseeker's allowance. In the case, the Court clarified that it might be regarded as justifiable for a Member State to base entitlement to a benefit, such as income-based jobseeker's allowance, on the condition that the applicant had remained in the host Member State for a sufficient period so as to establish a genuine link with the employment market. However, the Court also emphasiszed that when requiring a period of past residence,

'the period must not exceed what is necessary in order for the national authorities to be able to satisfy themselves that the person concerned is genuinely seeking work in the employment market of the host Member State' (para. 72 of the judgement).

The process of defining and clarifying the boundaries of and conditions for entering the national social Communities continues. The Community legislature has also contributed to this process, albeit with considerable scope for the judiciary to interpret the actual meaning of the legislative text in the future. In the legislative hurry prior to the 2004 enlargement, the Council adopted directive 2004/38/EC on 29 April 2004, i.e. two days before the ten new Member States entered the Community. This new residence directive implies a considerable extension of cross-border welfare rights. The Directive eliminates the obligation for EU citizens to obtain a residence permit and introduces a permanent right of residence after five years of continuous residence. Furthermore, it restricts the scope for national authorities to refuse or terminate the residence of EU citizens. Concerning expulsion, it is interesting that article 27 (2) of the Directive incorporates the principle of proportionality. The insertion of the principle in the legislative text substantiates that 
proportionality reviews will further limit the discretionary scope of the national executive in the future. Article 27 (2) lays down that;

'Measures taken on grounds of public policy or public security shall comply with the principle of proportionality and shall be based exclusively on the personal conduct of the individual concerned' (Article 27 (2) of Directive 2004/38. Emphasis added).

Finally, the Directive sets out that entitlement to social assistance in another Member State in the future will depend on the residence status of the EU citizens. A person who has resided for less than five years in another Member State will enjoy the right of residence as long as s/he does not become an 'unreasonable burden' on the host country's social assistance system and are covered by sickness insurance in that country. Proving that an EU citizen is an 'unreasonable burden' on the social system may be difficult for the Member State when, as demonstrated in the cluster of case-law cited above, recourse to social assistance in itself is not sufficient reason and not proportionate.

\subsection{The justifiability of national residence tests}

Regarding the proportionality and justifiability of national residence tests in the light of enhanced free movement and citizenship rights, the line of case-law suggests that residence clauses are increasingly being challenged. Collins, referred to above, illustrates this challenge. In terms of national legislation, the case concerns the UK habitual residence test, which was introduced in the UK in 1994. The test applies to income-based jobseeker's allowance, income support and the pension credit, and means that one must be accredited as 'habitual resident' in order to be entitled to these social rights. The habitual residence test was first challenged in Swaddling and its application found to be incompatible with Community law. ${ }^{\text {viii }}$ In Swaddling, the Court concluded that anyone who had exercised the right to free movement, established habitual residence in another Member 
State and then returned to their Member State of origin, in this case the UK, could not have their entitlement to income support made dependent on passing the habitual residence test. The habitual residence test was reformed in response to Swaddling by reducing the period of habitual residence enquiries from five to two years (Roberts, 2004).

Despite this move to comply with Community law, the UK habitual residence test continues to be contested. Union citizens and non-governmental organizations have argued that the burden of satisfying the test falls unequally on EU citizens in comparison with UK nationals. National regulations do not define 'habitual residence', and the applicable rules to satisfy the test appear complicated. Before the ECJ started to question the justifiability of the test, the discretionary scope to decide whether one satisfied the test was entirely left to the national administration. Among other factors, the criteria include where a person normally lives, where they expect to live in the future, the length of time spent abroad, and the ties with the country of origin (www.disabilityalliance.org/f46.htm). Collins refocuses attention on the habitual residence test. Albeit in a rather ambiguous manner, the case casts doubt on the compatibility between the residence test and community law. On the one hand, the Court states that Union citizenship does not preclude national legislators from making entitlement to income-based jobseeker's allowance conditional on satisfying a residence requirement. On the other hand, the Court emphasizes that in order to be justified in Community law, the habitual residence test must be based upon objective criteria which are independent of the nationality of the person concerned and that free movement has been exercised (see para 72 of the Collins case).

New questions regarding the habitual residence test have been raised. In the context of enlargement, the UK habitual residence test has been reinforced ${ }^{\mathrm{ix}}$, and in addition to being 'habitually resident', 
claimants must now also prove that they have 'a right to reside' by satisfying that they have the sufficient economic resources not to become a burden on the social security system. According to the UK government, the underlying purpose of the amendment has been to 'safeguard the UK's social security system from exploitation by people who wish to come to the UK not to work but to

live off benefits' (Report by the Social Security Advisory Committee, 2004, p. 3). This tightening of the habitual residence test has been criticized for going against the parallel development of Union citizenship and thus incompatible with the current state of EC law. It is argued that a new test has added complexity to rules whose application was already unclear, lacks transparency as well as a comprehensive legal definition (Report by the Social Security Advisory Committee, 2004). As with 'habitual resident', 'self sufficiency' is a difficult concept to apply in practice and may be difficult for an individual to prove should transparent and objective criteria be lacking. Nevertheless, the administrative practices of national authorities, deciding entry or exit as well as the social rights of the applicant, must pass the proportionality test written into Community legislation and reviewed by the ECJ. The inner core of national control is increasingly addressed, also in regard to the national welfare communities.

\subsection{Immigration Policies: A Policy Domain of National Control?}

One of the public policy areas in which national control has become increasingly tight is in the immigration policies of the respective EU Member States. Whether as a response to public opinion or economic recession, policies have been targeted to select between immigrants and hinder unwanted immigration. Despite the development towards a common European immigration policy, the administrative reality of national policies is by and large nationally controlled. The immigration policies in the EU Member States filter the entry and residence rights of third-country nationals 
through a wide web of conditions and administrative discretion to such an extent that the policy domain has long been one in which national sovereignty seems to remain intact.

Policies and administrative practices on family unification concretely demonstrate a reinforced national control of EU Member States. When immigration policies became stricter in response to the economic crisis after 1973, guest worker countries continued to allow entry to the family members of settled migrants. In this way, immigration was largely determined by family unification up until the late 1980s. Beginning in the early 1990s, many EU Member States added various conditions on the right to be unified with one's family in order to limit immigration by means of family unification. Conditions such as the availability of appropriate housing, sickness insurance and sufficient resources have been adopted as policy means with which to reject the residence of a family member (Cholewinski, 2002). These conditions have been supplemented by further criteria such that the person applying for family unification must be a certain age, the couple must have greater attachment to the country of application than to the country where the family member comes from, language and cultural tests for family members to maintain residence rights, etc. Such criteria have gradually entered national policies and become effective means for restricting the right to family reunification.

The ECJ case-law increasingly challenges the restrictive policies of Member States as regards the family right of European citizens who have exerted free movement. The free movement rights of Community workers and subsequently European citizens thus challenge the many criteria bound into national policies and administrative practices as means to limit immigration through family unification. The line of case-law detailed below again demonstrates the Court's ability and willingness to question the justifiability and proportionality of a set of public policies defining the 
territorial boundaries between 'them' and 'us'/'insiders' and 'outsiders' of contemporary nationstates. In assessing the justifiability and proportionality of the means by which to select who shall be included in the national community, the Court touches another remaining - but vital - fibre of national control and sovereignty.

\subsection{The right to be a family}

On 25 July 2008, the Court produced another milestone in the perilous terrain of national policies of high political salience, removing another threshold conditioning the right to reside;

'A non-community spouse of a citizen of the Union can move and reside with that citizen in the Union without having previously been lawfully resident in a member state. [...] the Court holds that a non-Community spouse of a Union citizen who accompanies or joins that citizen can benefit from the directive ${ }^{\mathrm{x}}$, irrespective of when and where their marriage took place and of how that spouse entered the host Member State' (from the ECJ press release No. 57/08, on Case C127/08 Metock, 25 July 2008, emphasis added).

The Metock judgement subsequently triggered a significant uproar among member governments, immigration ministers and national parties. British Immigration Minister Liam Byrne declared, 'We are crystal-clear that there is a risk of injustice that flows from this judgement and we are not prepared to see it' (European Voice, October 2, 2008), and numerous Danish MPs suggested simply ignoring the impact of the judgement on Danish immigration policy. Both responses indeed challenged the legitimacy of the Court.

Metock represents the temporary climax on the line of case-law that interprets national policies and administrative practices concerning immigration against the Community right to free movement and Union citizenship. ${ }^{\mathrm{xi}}$ Carpenter was among the earlier cases ${ }^{\mathrm{xii}}$. In 1994, Mrs Carpenter from the Philippines was given a six-month residence permit in the UK. After the end of the six-month 
period, she did not apply for a new residence permit but remained nevertheless. In 1996, she married Mr Carpenter, a UK national. Mr Carpenter ran a business based in the UK, but he often travelled to other EU Member States for short periods as part of his business. Subsequent to their marriage, Mrs Carpenter applied for a residence permit as the spouse of a Community national. Her application was refused, and the British authorities subsequently issued a deportation order against Mrs Carpenter. The case was then referred to the ECJ.

The UK government submitted that Mr Carpenter had not exercised his right to free movement and his spouse was therefore not entitled to rights from Community law. However, the Court found that the case was not to be regarded as entirely domestic, since Mr Carpenter provided cross-border services. The Court held that the national decision to deport Mrs Carpenter did not 'strike a fair balance' between the respect for Mr Carpenter's family rights and the national considerations, such as the maintenance of public order and safety (para. 43 of the case). The national decision to deport was found disproportionate to the pursued objective. Although the case contains a minimal link to the Community economic dimension and free movement, Mrs Carpenter was protected against what was found to be disproportionate national regulation (Spaventa 2004).

The Court's assessment of disproportionate national policies and actions continued in the MRAX case $^{\text {xiii }}$ (Dougan 2006). MRAX was brought against Belgium by the movement against racism: MRAX. The movement held that Belgian law and the administrative practices concerning the rights of third-country nationals married to European citizens ran counter to the Community legislation on free movement and the right to reside. Among other aspects $M R A X$ argued that the administrative practices of the Belgian authorities did not provide legal certainty to the spouses of Member State nationals and that this could have discriminatory effects. 
The Court considered the administrative practices in the light of the principle of proportionality. The Court thus emphasized that national practices - although they might find justification in a strict or narrow reading of Community law - could not hinder the effective objective and meaning of Community legislation. So as pointed out in the cases on Union citizenship and welfare by Spaventa, we here again see that national acts which may be justified by secondary legislation are found unjustifiable and disproportionate in their effects by the ECJ (Spaventa 2008). In its interpretations, the Court clarified that the Community legislature had attached importance to the protection of family life. The right to be a family was therefore understood as the Community objective that the national actions were assessed against. Against this objective, the Court found it disproportionate to send a third-country spouse back to their country of origin in order to prove their identity and family ties (paras. 61 and 62 of the judgement). Nor was it proportionate to make the issuing of a residence permit dependent on whether the spouse had entered the territory of a Member State lawfully. Furthermore, issuing an expulsion order from national territory on the sole grounds that a visa had expired constituted 'a sanction manifestly disproportionate' to the gravity of the breach of national provision made (para. 90 of the judgement).

The court also considered the question of prior lawful residence, stating that it

'is not permitted to refuse issue of a residence permit and to issue an expulsion order against a third country national who is able to furnish proof of his identity and of his marriage to a national of a Member State on the sole ground that he has entered the territory of the Member State concerned unlawfully' (para. 80 of the judgement. Emphasis added).

The question of the importance attributed to lawful residence continues to a set of subsequent cases. However, Akrich $^{\mathrm{xiv}}$ came to contradict that which the Court began concerning prior lawful residence in MRAX. In Akrich, the Court concluded that in order to benefit from the free movement provision, 
the spouse of a Union citizen must be a legal resident in one Member State when they move to another Member State. Akrich thus restricted the more expansive interpretation in MRAX. The subsequent case of $\mathrm{Jia}^{\mathrm{xv}}$ did not clarify the status of prior lawful residence. Instead, the Court continued in $\operatorname{Eind}^{\mathrm{xvi}}$ and laid down that the fact that the third-country national, daughter of a Union citizen, had not previously lived in a Member State was not relevant for the consideration of the case.

The unanswered question of the justifiability of prior legal residence as a national condition brings us back to Metock in July 2008, which can be seen as a path-breaking case due to how it outright contradicts the dominant restrictive pattern of national immigration policies concerning family unification. Metock addressed the rights of four spouses from third countries who were married to Union citizens who had established themselves in another Member State: Ireland. The four spouses had previously been refused asylum in Ireland. Furthermore, they had each been refused the right to reside as the spouse of migrating EU citizens due to the fact that they had not previously resided legally in another Member State, having entered Ireland directly from third countries with no right to enter or reside.

In Metock, the Court interpreted the impact of the new residence directive 2004/38. The Court's interpretations substantiate that the 2004 residence directive is likely to become a strong referring point for the enhancement of the rights of European citizens to become full members of national communities. The Court clarified the purpose of the new directive. The ECJ emphasized that the Directive aimed to strengthen the rights of EU citizens. On that background, Union citizens could not derive less rights from the new Directive than from the previous secondary legislation that it amended or replaced (para. 59 of the judgement). 
The case also demonstrates that the Court is not bound more by its previous interpretations than it can reconsider them and introduce new reasoning. Metock abandoned the previous lawful residence requirement laid down in Akrich;

'It is true that the Court held in paragraphs 50 and 51 of Akrich that, in order to benefit from the rights provided for in Article 10 of Regulation No 1612/68, the national of a non-member country who is the spouse of a Union citizen must be lawfully resident in a Member State when he moves to another Member State to which the citizen of the Union is migrating or has migrated. However, that conclusion must be reconsidered. The benefit of such rights cannot depend on the prior lawful residence of such a spouse in another Member State' (Case C127/08, Metock, para. 58. Emphasis added).

The interventions of the ten Member States in the case bear 'testament' to the grand political importance accorded to the case (Costello, 2009, p. 597). Nevertheless, the Court's interpretations directly contradicted the understandings stated by the Member States of what their exclusive competences were. The Court was by no means politically restrained in Metock. On the contrary, it outright stated that the interpretations put forward by the Irish Ministry of Justice and several other Member State governments - that Member States retain exclusive competence to regulate the first entry to a Community territory - had to be rejected (para. 66 of the judgement). Moreover, the Court was unresponsive towards other political observations submitted by the Member States. The Irish Ministry of Justice and several other governments had forwarded that it was necessary to control the external borders of the Community in the contemporary context of strong migration pressure and that it was therefore necessary to examine all of the individual circumstances of a first entry into the Union territory. The Member States argued it necessary to require prior lawful residence in another Member State as an entry condition. Otherwise, the ability of Member States to control their external borders would be undermined (para. 71 of the judgement). The Court refuted the political 
arguments by listing the remaining means that Member States have to control such entry. The Court pointed out that residence could be refused on the grounds of public policy, public health or public security or if abuse or fraud could be proved, such as marriage of convenience (paras. 74-75 of the judgement). However, such measures had to be proportionate and subject to procedural safeguards (paras. 75 and 97 of the judgement). ${ }^{\text {xvii }}$

\subsection{National implications of judicial integration}

Given the political salience paid to immigration policies, the Court's interventions in the field have not been lightly received by Member State governments. In addition, the line of case-law has had a direct impact on national policies. The legal clarifications thus exemplify Europeanization through judicial policy-making.

Denmark has been one of the very affected Member States. Restrictive immigration legislation has increasingly been pursued by the Conservative-Liberal government and its support party: the rightwing Danish People's Party. One of the restrictive measures adopted by the government has been on family unification, argued to foremost target marriage of convenience. Despite a specific target, restrictions hit generally. Danish citizens, Union citizens and residence-permitted third-country nationals have experienced severe restrictions on the residence rights of spouses with non-EU nationality.

Danish and Union citizens have increasingly used Community law to circumvent restrictive Danish policies. The 'Dublin hop', according to which British families move to Ireland in order to fall within the scope of Community law (Costello, 2009, p. 610), has a Nordic parallel, namely the Malmö route. For years, Danish and European citizens have circumvented restrictive Danish 
policies by establishing themselves in the neighbouring Swedish city of Malmö, hereby enjoying the rights as migrating Union citizens to reside together with their third-country spouse. However, for those interested in reducing their period of residence in Sweden and returning to Denmark with their family as quickly as possible, residence rights remained conditioned by Danish law. National conditions such as the availability of appropriate housing, sufficient economic resources, employment of a certain period of time in another Member State, residence of a certain period of time in another Member State, the applicant being more than 24 years of age, lawful residence, etc. have effectively limited the right to family unification in Denmark in defiance of Community law. As seen with the UK rules on 'habitual residence', the whole area lacks legal certainty and there are few clearly settled criteria as to what suffices to grant the right to reside as the third country family member of an EU citizen. For example, there is no exact definition of how long one must stay in another member state to be able to return to Denmark with one's non-EU family. That depends on an individual assessment. Danish administrative practice has proven to have its own interpretations of when and how migrating Union citizens can benefit from the EU rules.

Nevertheless, the pressure to adapt to the dynamics of Community law has intensified. In response to the Court's line of case-law, Danish immigration conditions have been forced to undergo significant change. In the early summer of 2008, the Danish newspaper 'Berlingske Tidende' questioned and examined the practices of Danish immigration services in the light of EU law. That resulted in a significant debate in the Danish press. The press took an agency role to put pressure on established political and administrative practices, and in this way brought EU rules and rights to the fore of the public debate. As a result, a judicially caused Europeanization of Danish immigration policies is indeed evident. The Danish Immigration Service now makes this clear (www.nyidanmark.dk/en-us/frontpage.htm): 
- there is no longer a minimum requirement for the length of the Danish national's residence in the other EU state;

- as a consequence of Eind, the Union citizen need not be economically active for the family's right to reside upon their return to Denmark;

- as a consequence of Metock, a family member is not required to have had previous lawful residence in another EU Member State; and

- as a consequence of Carpenter, Union citizens residing in Denmark but providing cross-border services to other EU Member States may be entitled to family reunification under EU law in exceptional cases.

Moreover, a de facto effect is evident. In 2009, three times more individuals were granted family unification with reference to the EU rules than in 2008 (Danish Immigration Service, yearly report “Tal og Fakta på Udlændingeområdet”, spring 2010). ${ }^{\text {xviii }}$ The case thus demonstrates the impact of judicial Europeanization, in both administrative practices and de facto terms.

\section{Concluding Remarks}

The principle of proportionality is one of the key instruments available to the Court for use when considering the justifiability of national conditions and administrative actions which constitute barriers to the purposes of the European Union. Proportionality assessments are thus important means of how the European Court furthers both judicial policy-making and Europeanization. Discrete and gradual, but very effective. 
Traditionally, the principle has been exerted to govern the economic community, but the Court has gradually become more daring, more pervasive, turning the principle into a general one and applying it with equal strength to policy areas of strong national legacies and political salience such as welfare and immigration policies (De Burca, 1993; Tridimas, 2006; Spaventa 2008). The principle thus intervenes in policy areas where high national thresholds are set to condition access and membership of the national communities and becomes the prism through which the justifiability of such thresholds are evaluated in the light of Community law. As we have seen in the analysis above, the balance is often struck in favour of Community law. Thus national conditions such as self-sufficiency, prior lawful residence, a true exercise of free movement, habitual residence, language and cultural ties, exerted on a discretionary basis and often lacking comprehensive legal definitions are increasingly evaluated by the European judiciary. Although member governments feel assured that their policy execution is justified and legitimated by secondary Community law itself, the ECJ's assessment may find the contrary.

The inherent tensions between the rules and norms of the EU and the administrative powers of the Member States are at play when the Court reviews national actions through the prism of proportionality. Legal scholars have long pointed out the principle of proportionality as a most powerful weapon when the judiciary strikes the balance between supranational rules and norms and national policy conditions and discretionary administration. Also political scientists should devote more attention to the principle. Its considerable political impact becomes evident for at least three reasons.

Firstly, it increases the opportunity for judicial intervention in both governmental and administrative decision-making. Secondly, it is no longer a principle which the judiciary reserves 
for assessments of inter-state trade, but is increasingly invoked against the entire range of fundamental EU principles and national policies. Thirdly, as invoked within the broadest spectrum of regulatory domains, it intervenes in the delicate balance between national and EU competences. Meanwhile, it constitutes a means of EU policy creation, it reduces the national scope of policy options, as national aims, means and conditions are evaluated in the European courtroom. It is thus a means of both judicial policy-making and subsequent Europeanization.

The analyses of Court interpretations and national responses regarding social minimum benefits and immigration policies demonstrate that we face new limits to the actions of the national executive. National policy options are narrowed when the European judiciary creates policies; not suddenly, but in very gradual moves and through creative means of interpretation. The inner core of national control, i.e. the power to detail, condition and administer national policies, must increasingly pass the Community proportionality test in almost all policy domains. The European Court of Justice hereby powerfully intervenes in the selective means of contemporary policies and the various thresholds set to enter national communities.

Word count: 8132 words

Biographical note: Dorte Sindbjerg Martinsen is Associate Professor at University of Copenhagen, Department of Political Science.

Address for correspondence: Dorte Sindbjerg Martinsen, University of Copenhagen, Department of Political Science, Øster Farimagsgade 5, 1353 Copenhagen K, Denmark. Email: $\underline{\mathrm{dm} @ \text { ifs.ku.dk }}$ 


\section{References}

Blichner, L.C. and Molander, A. (2008) 'Mapping Juridification', European Law Journal 14 (1): $36-54$.

Cholewinski, R. (2002) 'Family Reunification and Conditions Placed on Family Members: Dismantling a Fundamental Human Right', European Journal of Migration and Law 4: 271-290.

Conant, L. (2002) Justice Contained - Law and Politics in the European Union, Ithaca/ London: Cornell University Press.

Costello, C. (2009) 'Metock: Free Movement and 'Normal Family Life" in the Union', Common Market Law Review 46: 587-662.

Craig, P. and De Búrca, G. (2008) EU Law. Text, Cases, and Materials, Oxford: Oxford University Press.

De Búrca, G. (1993) 'The Principle of Proportionality and its Application in EC Law', Yearbook of European Law 13: 105-151.

Dougan, M. (2006) 'The constitutional dimension to the case law on Union citizenship', European Law Review 31: 613-641. 
Hailbronner, K. (2005) 'Union Citizenship and Access to Social Benefits', Common Market Law Review 42: 1245-1267.

Jacobs, F.G. (2007) 'Citizenship of the European Union - A Legal Analysis', European Law Journal, 13 (5): 591-610.

Martinsen, D.S. (2009) 'Conflict and Conflict Management in the Cross-border Provision of Healthcare Services', West European Politics 32 (4): 792-809.

Olsen, E.D.H. (2008) 'The Origins of European Citizenship in the first two Decades of European Integration', Journal of European Public Policy 15 (1): 40-57.

Radaelli, C.M. (2003) 'The Europeanization of Public Policy'. In Featherstone, K. and Radaelli, C. (eds) The Politics of Europeanization, Oxford: Oxford University Press.

Roberts, S. (2004) “'A Strong and Legitimate Link”. The Habitual Residence Test in the United Kingdom. Co-ordinating Work-Based and Residence-Based Social Security’. Faculty of Law, University of Helsinki.

Scharpf, F.W. (2001) 'Notes towards a theory of multilevel governing in Europe', Scandinavian Political Studies 24 (1): 1-26.

Scharpf, F.W. (2009) 'Legitimacy in the multilevel European polity', European Political Science Review 1 (2): 173-204. 
Spaventa, E. (2004) 'From Gebhard to Carpenter: Towards a (Non-)Economic European Constitution', Common Market Law Review 41: 743-773.

Spaventa, E. (2008) 'Seeing the Wood despite the Trees? On the Scope of union Citizenship and its Constitutional Effects', Common Market Law Review 45: 13-45.

Stone Sweet, A. and Mathews, J. (2008) 'Proportionality Balancing and Global Constitutionalism', Columbia Journal of Transnational Law 47: 72-165.

Tridimas, T. (2006) The General Principles of EU Law, Oxford: Oxford University Press.

Wasserfallen, F. (2010) 'The Judiciary as Legislator? How the European Court of Justice shapes Policy-making in the European Union'. In Journal of European Public Policy, Vol. 17, No. 8, forthcoming.

Wind, M. (2009) 'Post-National Citizenship in Europe: The EU as a "Welfare Rights Generator"'. The Columbia Journal of European Law, Vol. 15, No. 2, pp. 239-265. 


\section{Notes}

${ }^{i}$ See Case C-438/05, Viking, 11 December 2007, para 46; Case C-341/05, Laval, 18 December 2007, para 94; Case C346/06, Rüffert, 3 April 2008, paras 40-42 and Case C-319/06, Commission vs. Luxembourg, 19 June 2008, paras 5153.

${ }^{\text {ii }}$ Case C-184/99, Grzelczyk, 20 September 2001.

${ }^{\text {iii }}$ Case C-456/02, Trojani, 21 November 2002.

iv Article 1 of Council Directive 90/364/EEC of 28 June 1990 on the right of residence.

${ }^{v}$ Case C-413/99, Baumbast, 17 September 2002.

${ }^{\mathrm{vi}}$ Also the later case of Bidar continued to enhance the residence rights to those without a 'genuine link with the economic market', Case C-209/03, Bidar, 15 March 2005.

${ }^{\text {vii }}$ Case C-138/02, Collins, 23 March 2004.

${ }^{\text {viii }}$ Case C-90/97, Swaddling, 25 February 1999.

${ }^{\text {ix }}$ By the Social Security (Habitual Residence) Amendment Regulations 2004, Statutory Instrument 2004. no. 1232.

${ }^{x}$ I.e. the residence directive 2004/38/EC.

${ }^{x i}$ The point of departure for the Court's expansion of the rights of non-Community family members was the Singh case from 1992; C-370/90, Singh, 7 July 1992.

xii Case C-60/00, Carpenter, 11 July 2002.

xiii Case C-459/99, MRAX, 25 July 2002.

${ }^{\text {xiv }}$ Case C-109/01, Akrich, 23 September 2003.

${ }^{\mathrm{xv}}$ Case C-1/05, Jia, 9 January 2007.

${ }^{\text {xvi }}$ Case C-291/05, Eind, 11 December 2007.

${ }^{\text {xvii }}$ See also the more recent cases C-310/08 and C-480/08, Ibrahim and Teixeira, 23 February 2010, where the Court followed suit and continued extending the rights of third country nationals with reference to the free movement principle of Community law.

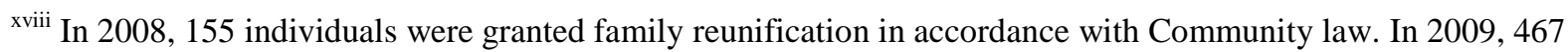
persons were granted the same right. See the yearly report from the Danish Immigration Service "Tal og Fakta på Udlændingeområdet", spring 2010, p. 35. 